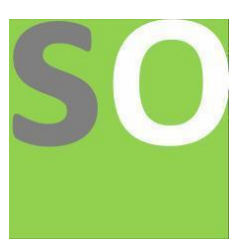

Article title: Open-Source Intelligence (OSINT) and Relationship Building techniques for Frontline Humanitarian Aid Workers

Authors: Ahmed Alameldeen[1]

Affiliations: Graduate of Department of Health Sciences, University of York, York, UK and a Humanitarian Aid Worker who used to work with the United Nations (UN), International Committee of the Red Cross (ICRC) and Doctors without Borders (MSF)[1]

Orcid ids: 0000-0003-2466-7515[1]

Contact e-mail: ahmed.alameldeen@alumni.york.ac.uk

License information: This work has been published open access under Creative Commons Attribution License http://creativecommons.org/licenses/by/4.0/, which permits unrestricted use, distribution, and reproduction in any medium, provided the original work is properly cited. Conditions, terms of use and publishing policy can be found at https://www.scienceopen.com/.

Preprint statement: This article is a preprint and has not been peer-reviewed, under consideration and submitted to ScienceOpen Preprints for open peer review.

DOI: 10.14293/S2199-1006.1.SOR-.PPZA1HW.v1

Preprint first posted online: 10 October 2021

Keywords: OSINT, Open-Source Intelligence, Humanitarian Affairs, Diplomacy, Negotiations 


\title{
Open-Source Intelligence (OSINT) \& Relationship Building techniques for Frontline Humanitarian Aid Workers
}

\author{
Ahmed Alameldeen ${ }^{1}$ \\ ${ }^{1}$ Graduate of Department of Health Sciences, University of York, York, UK and a Humanitarian Aid \\ Worker who used to work with the United Nations (UN), International Committee of the Red Cross \\ (ICRC) and Doctors without Borders (MSF)
}

Corresponding author: Ahmed Alameldeen

Contact: ahmed.alameldeen@alumni.york.ac.uk 


\begin{abstract}
$\underline{\text { Abstract }}$
Given the diverse nature of the conflicts around the world as well as the dynamic power relations putting more emphasis on the state and non-state actors, the activities and functionalities of the humanitarian organizations are prone to multiple challenges. A lack of the contextual understanding of the conflict at different levels of analyses, therefore, is fundamental to develop a structural understanding of the conflict and its geopolitical realities. The Frontline Humanitarian Aid workers need to develop diplomatic relationship with the native or the indigenous elements in the power amidst the conflict situation to communicate their mandate, and ensure cross-level humanitarian assistance. This communication and the relationship between the Interlocutors and the subjects need to be a two-way process where the information flow is smooth and transparent. Moreover, media tracking and monitoring via different digital avenues and the coding of information to create a valuable input can contribute to cope up with the posed challenges. These techniques in addition to the recommendations for the strength and optimization of the Network of the Interlocutors has been presented in the paper with the information based on empirical knowledge, primary, and secondary sources. The purpose is to provide the Front-line Humanitarian Aid workers in their humanitarian operations with new insights and relevant information to function properly. Moreover, the recommendations can also contribute to the efforts of the Humanitarian organizations to improve their acceptance and perception.
\end{abstract}

\title{
Introduction
}

This paper aims to illustrate the ways and techniques on how to build, strengthen and optimize the Network of Interlocutors who would have relevance to (i) Front-line Humanitarian Aid workers in their humanitarian operations, and (ii) the efforts of Humanitarian organizations to improve their acceptance and perception by State and Non-State Actors in their specific contexts. These ways and techniques are summarized in 4 Core Sequential Steps and 2 Continuous and ongoing tasks illustrated in the upcoming sections.

\section{Step 1: Detailed Studying of the Context \& Information Collection}

Humanitarian Aid workers always rely on Local National staff to understand the local context and the Political, Religious, Tribal and Cultural dynamics, to be able to use of it for the benefit of the Humanitarian Organizations' assistance and protection work. (Haver, 2007)

Based on the Author's experience, the 2 main ways to start understanding the local context would be:

1- Reading Books.

2- Watching Documentaries.

The Books and Documentaries should be related to the local context in the relevant dynamics mentioned above (political, religious, tribal and cultural), and at later stages, subjects focusing on geopolitics, to have a bigger understanding picture on the situation. 


\section{Recommendations:}

1- Identify twelve Books to Purchase and start reading 2 books per month for the next 6 months.

2- Since the Books' Authors and Documentaries' makers have an interest in the context that also you are working in, it is important while reading the books and watching the documentaries, to write down their names and their background information.

3- Record the names of the members of the important State and Non-State Actors mentioned in the books and documentaries in a list, and check their current influence and history. Also, check the history of those members with your own organization and if they ever met before.

4- Try to connect the information together and make links that make sense to your humanitarian organization's efforts in reaching the central command or decision makers of their relevant State and Non-State actors, that would eventually help in building the relationship with them, for the purpose of frontline humanitarian negotiations if needed.

\section{Step 2: Contacts Gathering and Meetings Proposals}

There are several types of Interlocutors who are important to meet (whether face-to-face or virtually), the purpose of the meeting should not be information gathering, but rather to disseminate and explain to them the work and activities done by the humanitarian community, and grabbing their interest on how the work of the humanitarian community is important to them as well.

Based on the Author's experience, most of the Intellectual Interlocutors who would have a decision making that would impact the humanitarian community's work, or act as advisors to decision makers, are not aware of the mandate and level of engagement of the humanitarian organizations, and always interpret the work in a wrong way as being Spies, foreign agents, conspiracy makers, etc...

When you start meeting with these Interlocutors, you will find that they are very interested to hear about the humanitarian assistance efforts, especially the frontline ones with activities involving any cross-line humanitarian assistance (delivering assistance to both parties of conflict) as per UN policies. (The United Nations, 2021)

Moreover, they will be sometimes willing to provide you info and advice that could help in your work, but at the same time will not jeopardize their privileged access or delicate positions and roles that they have.

\section{Types of Interlocutors to connect with:}

1- Books' Authors and Writers.

2- Documentary makers.

3- Relevant Religious Scholars and Clan/Tribal leaders interviewed in the books and documentaries and other non-traditional actors and local diasporas. (DEMAC \& OWL RE, 2021)

4- Countering/Preventing Violent Extremism (C/PVE) practitioners. (Abby Stoddard, 2011)

5- Think Tanks.

N.B. These Interlocutors are meeting the same decision makers who your organization would be interested to meet and discuss topics like Humanitarian access to specific areas or any other critical subject that would result in delivering more aid to the people in need. 
So, they understand their mindset, and they can provide you with very valuable advice about these important subjects and matters.

\section{Recommendations:}

1- Try to get the official contacts of the Authors collected in Step 1 and check the possibility to meet the ones accessible, whether in the country you work in, or in a neighboring country.

2- Identify the C/PVE Practitioners working in your context using LinkedIn, and follow them to see the topics they write about and share interests for. Also, they will be sharing upcoming events and conferences about these topics that will be very beneficial to attend. (Ghannam, 2016)

Those relevant (start with International not local C/PVE practitioners) and your organization would like to meet with, you can send them an official message on LinkedIn to arrange a meeting.

3- Religious scholars love reading, and allocating a small budget to purchase Intellectual Books and offer it to them as a Gift, proven to be beneficial initial ice breaking step.

\section{Step 3: Interlocutor Profile Creation}

This step is important for Documentation purposes and to be able to share the created profiles with the concerned departments and offices. Profiling needs to be done for the relevant Interlocutors and not everyone we meet, and we need to state how this Interlocutor could be helpful to your organization whether in the short or long term.

Ideally, a profile needs to be created when a face-to-face or a virtual meeting (Skype for example) has taken place, but because of many factors related to access and security, you might not be able to meet with all Interlocutors, but still Profiling the relevant ones that you cannot meet will be of importance. (International Committee for Red Cross)

\section{Step 4: Educating the Interlocutors about the Humanitarian Community}

This step is not considered only Dissemination (although Dissemination sessions are part of it), but the Education concept focuses more on providing regular and consistent information to the Interlocutors directly, using the common methods of communication available in the context (WhatsApp, Telegram, Facebook, Viber, etc...). (Ghannam, 2016)

The purpose of this step is to send regular "open source" news, updates and videos about the different humanitarian activities and thematic locally and regionally (depending on the Interlocutors' interest and their areas' of influence).

The Educating step is very important because your Humanitarian organization needs always to search for Influencers who could answer on their behalf and defend it with their influence, at the time when there are false allegations or misperception issues, or if they will act as intermediaries between the humanitarian community and non-state armed groups. 
Humanitarian Aid workers cannot be present everywhere, and cannot know all the allegations against them, that is why, investing time and effort in educating the Interlocutors regularly and continuously is of great importance, especially on the long run.

Many opportunities could arise from educating our Interlocutors, it just needs a proper strategy, time and patience.

\section{Recommendations:}

1. Dedicate a Smartphone to use for this task.

2. Identify the Most common communication method (could be written) used by the Interlocutors in your context and send to them weekly message about your humanitarian organization activities or their mention in the news.

3. Try to Categorize the Interlocutors based on their Interest, for example, if you work in Nigeria and a scholar is interested in news about what is happening in Syria. So, sending them updates about activities around their topic of interest, will be appreciated and might open the door for more discussions, that will eventually be helpful for your work.

4. Whenever and wherever feasible, it is worth to invite some Interlocutors for round table discussions with your organization's leadership to exchange ideas and insights, and to provide the opportunity to listen to their opinion and perspective on some relevant topics.

\section{Ongoing Task 1: Media Tracking and Monitoring}

This task is about monitoring the visual, audible and social media of the Interlocutors, by keeping a close eye on what they publish and what topics Interest them, is a very crucial and important task for the success of the above mentioned 4 steps.

\section{Media Types (the most common):}

Claims: Claiming an Attack towards governmental forces or another non-state actor in a specified location and time (sometimes with the purpose mentioned).

Infographics: Visual Representation to summarize attacks in a specific area or a specific period.

$>$ Local News: Social or Humanitarian activities took place in their area of control towards the community.

$>$ Videos: Delivering a message to their supporters and enemies or a video documenting a military attack.

Audios: Radio Broadcasting of their Daily Activities or an Audio message to their supporters and enemies. 


\section{Automating the Media Tracking and Monitoring}

Depending on the context, the process of Media Tracking and Monitoring can be hectic and requires too much work, especially in conflict situations where the context is dynamic and rapidly changing. That is why, we need to use tools that help in making the Tracking and Monitoring automated and receive Daily or Weekly alerts depending on the urgency. This is done by adding specific keywords (one word or sentences) and receive an alert based on these Keywords.

\section{External Monitoring \& Tracking Tools:}

Google Alerts: Using Keywords to Monitor News, Facebook and Blogs. ${ }^{1}$ (Miessler, 2021)

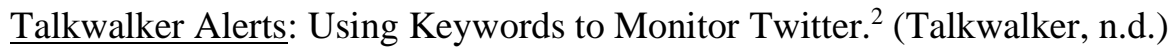

$\underline{\text { Social Searcher: Using Keywords to Monitor All social media (more for historical news) }}{ }^{3}$

Jihadology: Source for Jihadi Publications (Free but requires Signup and approval) ${ }^{4}$ (Jihadology, n.d.)

Stratfor: Geopolitical Analysis Platform ${ }^{5}$ (Stratfor, n.d.)

TRAC: Terrorism Research \& Analysis website ${ }^{6}$ (Craft, 2019)

SITE: Breaking News, Articles, and Analysis about Jihadi movements

Telegram: Channels following your context news ${ }^{7}$ (International Committee for Red Cross)

\footnotetext{
${ }^{1}$ Google Alerts is a content change detection and notification service, offered by the search engine company Google. 2 Talkwalker is a company to monitor different forums, news sites, blogs, and reviews etc. on all markets in 198 languages.

${ }^{3}$ Social Searcher is a free Social Media search engine that allows you to monitor all public social mentions.

${ }^{4}$ Jihadology is an academic website that is a Sunni Jihadi primary source material. (Jihadology, n.d.)

${ }^{5}$ Stratfor corporation is an American online geopolitics publisher founded in 1996.

${ }^{6}$ TRAC is an open source-intelligence (OSINT) repository that offers coverage of topics relevant to domestic and international terrorism. (Craft, 2019)

${ }^{7}$ A soft-ware used for cross-platform, cloud-based instant messaging system.
} 


\section{Types of Alerts and using suitable Keywords:}

"As-it-happens" Alerts: These are alerts designed for urgent matters by adding keywords related to Security incidents or tracking a Hostage/Abduction case. For example, using Keywords like "Mogadishu Explosion" or "Yemen Humanitarian Crisis" to receive "instant" alerts about these topics whenever there is any mention about them in the Internet. (Miessler, 2021)

Daily Alerts: These are alerts that are not necessarily urgent, but it is good to know about on a daily basis. For example, using cities' names as Keywords to receive news about what is going on it daily. It will be more relevant for offices who are covering different cities in their Areas of Responsibilities and would like to follow the updates there regularly. (Oracle, n.d.)

Weekly Alerts: These are alerts that are more Global and provide you with news and information that can feed our work in the contextual analysis. (Oracle, n.d.)For example, using Keywords like "Middle East Migrant Crisis" or even a name of an Interlocutor to follow his weekly posts.

\section{$\underline{\text { Recommendations: }}$}

1- Dedicate a Gmail account to receive the Alerts to and not to overwhelm your own inbox with many emails.

2- When creating an Alert, it is better to use the Keywords in different languages (English and Local) to make sure the monitoring is comprehensive. For example, if you work in Somalia, you will need keywords in Arabic and Somali languages, in addition to English.

3- Audit the Keywords and alerts regularly and remove those that are not useful. Also, add new keywords if new emerging issues occurred and requires monitoring for a period of time.

4- The person responsible for doing this Tracking and Monitoring task is the best one to decide which keywords to use and which Alert category they can fall in based on the understanding of the context and the field operations. There is no rule saying that an Interlocutor name should be used as a Weekly Alert (as mentioned up), rather, we need to have common sense about it.

\section{Ongoing Task 2: Making sense of the information \& Connecting the Dots}

This is not an easy task and not all the information received could be connected together and presented to your organization's decision makers. There is no recommendation on how to do it, but generally it requires "Mastering" all the 4 Steps mentioned above. Being able to perform the 4 steps will provide your organization with a comprehensive grasp on the situation from all its sides, and after some time, you will be able to connect information together even the Information that does not appear to be connected. 


\section{Cold, Warm \& Hot Audiences: What Humanitarian Aid Workers can learn from Marketers}

In the Marketing world, Marketers classify their customers and audiences that they want to sell to, into three Categories (Cold, Warm \& Hot).

A Market Growth company called "Single Grain" (Grabowski, n.d.)is defining these 3 Categories as:

“Cold Audience: Consists of people who have never heard of your business before. You should target cold audience to Introduce your brand or products \& begin building a relationship with them in an effort to turn them into warm audience.

Warm Audience: They are audience who have visited your site before, read your content, followed you on social media, but so far, they have indicated no interest in buying from you. In spite of the fact that they like your content, they haven't purchased yet. Your goal, therefore, is to run ads that will encourage warm audience to make a purchase.

Hot Audience: They are made up of people who have already bought something from you or trusted you (and didn't ask for their money back). In other words, they know you, your products or services quite well. And there's a good chance that they'll buy more-they could purchase additional products, upgrade their service or send more projects your way."

This classification could be adapted to Humanitarian organizations work, on how to build an Influencer Strategy and how to gradually improve the Acceptance and the Perception of Interlocutors towards the Humanitarian community.

When we look at the definitions above, we see that in many cases, the aid workers' approach is that we assume by default that all our Interlocutors and beneficiaries are "Hot Audience" and that they know the humanitarian organizations very well, and this is a mistake.

This whole report and steps mentioned above are built with the mind-set that we need to assume that our Interlocutors are actually "Cold Audience" and we need to invest time and effort to educate them about us the humanitarian workers, and moving them from the Cold Phase to become Warm and finally become Hot Audience.

\section{Free Online Analysis Training Courses}

$>$ Conflict Analysis Micro Course by United States Institute of Peace (USIP) - Link to Access: (https://www.usip.org/academy/catalog/conflict-analysis-micro-course) (United States Institute of Peace)

$>$ Understanding Terrorism and the Terrorist Threat by the University of Maryland - Link to Access: (https://www.start.umd.edu/events/free-online-course-understanding-terrorism-andterrorist-threat) (National Consortium for the Study of Terrorism and Responses to Terrorism, 2015)

$>$ Terrorism and Counterterrorism: Comparing Theory and Practice by Leiden University - Link to Access: (https://www.coursera.org/learn/terrorism) (Universtiet Leiden)

\footnotetext{
${ }^{8}$ Single Grain is a full service digital marketing agency focused on growth, accountability, and integrity.
} 
$>$ Security, Terrorism \& Counterterrorism by Murdoch University - Link to Access: (https://www.murdoch.edu.au/study/study-online/security-terrorism-counterterrorism-online ) (National Consortium for the Study of Terrorism and Responses to Terrorism, 2015)

$>$ Social Network Analysis by Center for Homeland Defense \& Security (CHDS) - Link to Access: https://www.chds.us/ed/items/tag/social-network-analysis) (NPS Center for Homeland Defense and Security)

$>$ Research Process \& Methods by Center for Homeland Defense \& Security (CHDS) - Link to Access: (https://www.chds.us/selfstudy/courses/research-methods/) (NPS Center for Homeland Defense and Security, 2013)

\section{$\underline{\text { References }}$}

Abby Stoddard, A. H. (2011). Safety and Security for National Humantarian Workers. Policy and Studies Series.

Craft, A. (2019). TRAC (Terrorism Research and Analysis Consortium). The Charleston Advisor, 44-50.

DEMAC \& OWL RE. (2021). Diaspora Organizations and their Humanitarian Response in Pakistan. Danish Refugee Council, USAID.

Ghannam, J. (2016). Media as a Form of Aid in Humanitarian Crises. Center for International Media Assistance.

Grabowski, P. (n.d.). Here's How Targeting Cold, Warm \& Hot Traffic Builds Successful Customer Relationships. Retrieved from Singlegrain: https://www.singlegrain.com/marketing-funnels/how-targeting-cold-warm-hot-trafficbuild-successful-customer-relationships/

Haver, K. (2007, July). Duty of care? Local staff and Aid Worker Security. Forced Migration Review, pp. 10-11. Retrieved from Forced Migration Review.

International Committee for Red Cross. (n.d.). Humanitarian Future for Messaging Apps. ICRC.

Jihadology. (n.d.). Retrieved from Lawfare: https://www.lawfareblog.com/topic/jihadology

Miessler, D. (2021, May 19). The Difference Between Events, Alerts, and Incidents. Retrieved from Daniel Miessler: https://danielmiessler.com/study/event-alertincident/\#gs.xhybxpc 
National Consortium for the Study of Terrorism and Responses to Terrorism. (2015, January 12). Understanding Terrorism and the Terrorist Threat.

NPS Center for Homeland Defense and Security. (2013, January). Research Process and Methods.

NPS Center for Homeland Defense and Security. (n.d.). Social Network Analysis. The United States of America.

Oracle. (n.d.). Agile Product Lifecycle Management Documentation Library. Retrieved from Oracle:

https://docs.oracle.com/cd/E50306_29/otn/pdf/administration/html_agabg/output/toc. htm

Stratfor. (n.d.). Retrieved from Wordview.stratfor: https://worldview.stratfor.com/

Talkwalker. (n.d.). Retrieved from Talkwalker: https://www.talkwalker.com/

The United Nations. (2021, July 9). Resolution 2585 (2021): Adopted by the Security Council at its 8817th meeting. Retrieved from United Nations Docs: https://undocs.org/S/RES/2585(2021)

United States Institute of Peace. (n.d.). Conflict Analysis: Micro-Course.

Universtiet Leiden. (n.d.). Terrorism and Counterterrorism: Comparing Theory and Practice. Netherlands. 
